\title{
ADDITION OF NITRATE FOR ODOR CONTROL IN SEWER NETWORKS: LABORATORY AND FIELD EXPERIMENTS
}

\section{V.L. MATHIOUDAKIS* \\ E. VAIOPOULOU \\ A. AIVASIDIS}

Selected from papers presented in $9^{\text {th }}$ International Conference on Environmental

Science and Technology (9CEST2005)

1-3 Septmber 2005, Rhodes island, Greece

\author{
Department of Environmental Engineering \\ Democritus University of Thrace \\ Vas. Sofias 12, 67100, Xanthi, Greece
}

*to whom all correspondence should be addressed e-mail: vmathiou@env.duth.gr

\section{ABSTRACT}

This paper presents a biological method for controlling odor problems caused by $\mathrm{H}_{2} \mathrm{~S}$ originating from sewer networks under anaerobic conditions. The proposed method is based on the continuous addition of nitrate which oxidizes dissolved sulphide according to an autotrophic biological procedure and inhibits further sulphide production by sulphate reducing bacteria, until complete denitrification.

The proposed method was first tested at laboratory in a $3 \mathrm{I}$ anaerobic batch reactor simulating municipal wastewater of the city of Corfu in respect to sulphate concentration. Addition of nitrate in non-septic (not sulphide containing) wastewater inhibits the production of sulphide until complete denitrification. Heterotrophic denitrification rate was found 4.5 and $3.9 \mathrm{mg} \mathrm{NO}_{3}$ $\mathrm{N}^{-1} \mathrm{~h}^{-1}$ at $25^{\circ} \mathrm{C}$ and $30^{\circ} \mathrm{C}$ respectively. Higher $\mathrm{C} / \mathrm{N}$ ratio is, probably, responsible for the increased denitrification rate of the lower temperature.

Interestingly, addition of nitrate in a septic wastewater led to a preferential autotrophic denitrification with sulphide as electron donor at a rate of 0.8 and $1.5 \mathrm{mg} \mathrm{NO}_{3}-\mathrm{N}^{-1} \mathrm{~h}^{-1}$ at 25 and $30^{\circ} \mathrm{C}$. After complete sulphide oxidation, heterotrophic denitrification takes place inhibiting any further sulfate reducing activity.

The effectiveness of the method was validated by field experiments in a $6.7 \mathrm{Km}$ combined sewer network in the city of Corfu, with an average wastewater flow of $500 \mathrm{~m}^{3} \mathrm{~h}^{-1}$, an average retention time of $2 \mathrm{~h}$ and sulphide concentrations varying from 3 to $27 \mathrm{mg} \mathrm{S}^{2-}{ }^{-1}$. Continuous addition of $6.9,15$ and $27.7 \mathrm{Kg} \mathrm{NH}_{4} \mathrm{NO}_{3} \mathrm{~h}^{-1}$ for a period of 4 to 8 hours led to an average sulphide removal efficiency of $84 \%, 98 \%$ and $99 \%$, respectively.

Based on these experimental results, a continuous addition of $10 \mathrm{Kg} \mathrm{NH}_{4} \mathrm{NO}_{3} \mathrm{~h}^{-1}$ is proposed for practical implementation as the optimal dosing, considering sufficient odor control and tolerable increase of the ammonia load. The proposed method is not only effective but also financially interesting taking into account the facility cost and the monthly operational cost, during the summer months of the year.

KEYWORDS: odor control, sewer network, septicity, hydrogen sulphide, denitrification, nitrate, combined sewer

\section{INTRODUCTION}

Because of the severe environmental and economic problems that arise from microbial hydrogen sulphide production its removal from wastewater has become mandatory. Hydrogen sulphide is affiliated with corrosion of metal and cement pipes [1], operational problems in wastewater treatment plants (WWTP) [2], as well as with hygiene and odor problems [3]. Among others chemicals inhibiting $\mathrm{H}_{2} \mathrm{~S}$ formation or removing sulphide from wastewater such as oxygen, hydrogen peroxide and ferric salts, addition of nitrate seems a promising 
technique when applied to fields like oil industries - to avoid oil souring or precipitation of metal sulphide in reservoirs [4], [5] - and sewer systems for odor control. Enterprises for drainage in Greece have to deal effectively with urban odor problems originating from sewer systems, especially during summer when tourist season reaches its peak.

In regard to sewer networks, microbial utilization of dissolved oxygen and nitrate leads to the prevalence of anaerobic conditions (septicity). A large number of substances, produced under anaerobic conditions, lead to odor problems, e.g. fermentation products, volatile organic compounds and hydrogen sulphide. From an engineering point of view, hydrogen sulphide can be considered the appropriate indicator for odor control in wastewater treatment plants and sewers [3], [6]. Hydrogen sulphide is microbially formed by sulphate reducing bacteria (SRB), principally by Desulfovibrio and Desulfotamaculum [3]. Sulphate heterotrophic respiration can be described by the following equation:

$$
4 \mathrm{CH}_{3} \mathrm{OH}+3 \mathrm{SO}_{4}^{-2}+2 \mathrm{H}^{+} \rightarrow 4 \mathrm{HCO}_{3}^{-}+3 \mathrm{H}_{2} \mathrm{~S} \uparrow+4 \mathrm{H}_{2} \mathrm{O} \quad \Delta \mathrm{G}^{0^{\prime}}=-92.8 \mathrm{KJ} \mathrm{mol}^{-1} \mathrm{MeOH}
$$

Although sulphide formation is typically recognized as a problem in pressure mains, it is also observed in gravity sewers with slow flow rates and insufficient reaeration, potentially at relatively high temperature [7], [8]. The factors determining sulphide production rate, under anaerobic conditions, are the concentration of sulphate, the concentration of organic matter, the hydraulics characteristics of the sewer system and the temperature of the wastewater.

For odor control in sewers, although several chemicals have been used, better understanding of chemical and microbial processes taking place have led to a greater use of nitrate [9]. Despite this fact, only one study until now [10], has presented the effectiveness of nitrate use for odor control under field conditions. Addition of nitrate for odor control favor its use among other chemicals due to its advantages like high solubility, low nitrate consumption rate and operational cost compared to addition of oxygen and also due to its no need for special occupational training in comparison to hydrogen peroxide or potassium dichromate. However nitrate continuous addition must be controlled in order to avoid the increase of nitrate concentration in the influent of the WWTP.

Addition of nitrate in a septic wastewater oxidizes biologically dissolved sulphide via autotrophic denitrification by sulphur-oxidizing denitrifying bacteria such as Thiobacillus denitrificans and Thiomicrospira denitrificans. Excess nitrate concentration, after sulphide oxidization, is reduced via heterotrophic denitrification inhibiting any further sulphide production. This inhibition can be explained, from a thermodynamic point of view, according to the change of the free energy reaction under standard conditions $\left(\Delta \mathrm{G}^{0^{\prime}}\right)$. Autotrophic and heterotrophic denitrification can be described by the following equations, respectively:

$$
\begin{aligned}
1.25 \mathrm{~S}^{-2}+2 \mathrm{NO}_{3}^{-}+\mathrm{H}_{2} \mathrm{O} \rightarrow 1.25 \mathrm{SO}_{4}^{-2}+\mathrm{N}_{2 \uparrow}+2 \mathrm{OH} & \Delta \mathrm{G}^{0^{\prime}}=-740 \mathrm{KJ} \mathrm{mol}^{-1} \mathrm{H}_{2} \mathrm{~S} \\
& =-462.5 \mathrm{KJ} \mathrm{mol}^{-1} \mathrm{NO}_{3} \\
5 \mathrm{CH}_{3} \mathrm{OH}+6 \mathrm{NO}_{3}^{-}+\mathrm{H}^{+} \rightarrow 5 \mathrm{HCO}_{3}^{-}+3 \mathrm{~N}_{2 \uparrow}+8 \mathrm{H}_{2} \mathrm{O} & \Delta \mathrm{G}^{0}=-649.5 \mathrm{KJ} \mathrm{mol}^{-1} \mathrm{MeOH} \\
& =-541.3 \mathrm{KJ} \mathrm{mol}^{-1} \mathrm{NO}_{3}
\end{aligned}
$$

\section{MATERIALS AND METHODS}

\subsection{Lab experiments}

Two sets of experiments were conducted, in a $3 \mathrm{I}$ anaerobic batch reactor with double jacket at two different temperatures $\left(25\right.$ and $\left.30^{\circ} \mathrm{C}\right)$. The first set of experiments studied the inhibition of sulfate respiration in a non-septic wastewater and the second set studied the autotrophic oxidation of sulphide in a septic wastewater, as well as the subsequent inhibition of its production via heterotrophic denitrification, by addition of $3 \mathrm{mmol} \mathrm{I}^{-1}$ potassium nitrate. In the first set, potassium nitrate was added initially while in the second after the production of a sufficient concentration of dissolved sulphide by sulphate respiration (approximately $5 \mathrm{mg} \mathrm{S} \mathrm{S}^{2-}$ $\mathrm{I}^{-1}$ ). At the beginning of its experiment $12 \mathrm{mmol}^{-1}$ sodium sulphate were added so that the 2.5 I mixed liquor would represent the wastewater of municipality of Corfu in respect to sulfate concentration.

The wastewater used, originated from the sewer system of municipality of Xanthi while the biomass was obtained from the first anoxic tank of a pilot scale biological nutrient removal unit 
[11].Experiments conducted in a period of months resulting to variations in the characteristics of the wastewater and biomass quality. Temperature was controlled with the use of thermostate bath recirculating water through the double jacket whereas the content was continuously stirred. At the initiation of each experiment nitrogen gas was introduced to ensure the absence of oxygen.

Soluble Chemical Oxygen Demand (centrifuged samples), $\mathrm{pH}$, total sulphide $\left(\mathrm{S}^{2-}\right)$ and Suspended and Volatile Suspended Solids (SS and VSS) were measured according to Standard Method for Examination of Water and Wastewater. Nitrate was analyzed with ion chromatograph (Hamilton column PRP X-100 and p-hydroxybenzoic acid as the eluent).

\subsection{Field experiments}

Field experiments conducted in the sewer system of municipality of Corfu. The investigated system, shown in Figure 1, has a length of $6.7 \mathrm{Km}$ with an average wastewater flow of $500 \mathrm{~m}^{3}$ $\mathrm{h}^{-1}$ and an average retention time of $2 \mathrm{~h}$.

After wastewater characterization, continuous addition of ammonium nitrate was applied to suppress septicity. The addition took place at the pumping station $A$ and the duration of the addition was 4 to 8 hours depending on the flow of the aquatic solution of ammonium nitrate. The solution was stored in a $1 \mathrm{~m}^{3}$ open tank and the addition was accomplished by free flow from a vent. Sampling began at least 3 hours later the initiation of the addition in order to achieve steady state conditions in the sewer system.

Temperature and $\mathrm{pH}$ were measured in situ. Samples for measurement of soluble COD, total sulphide $\left(\mathrm{S}^{2-}\right)$ and nitrate were refrigerated and measured immediately in the laboratory according to Standard Method for Examination of Water and Wastewater.

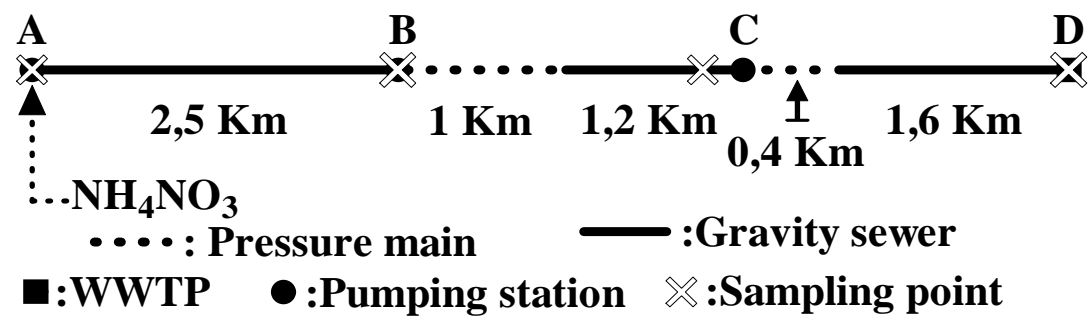

Figure 1. Investigated combined sewer system

\section{RESULTS AND DISCUSSION}

\subsection{Laboratory experiments}

In the first set of experiments, the presence of nitrate inhibits sulphide production, suppressing in this way odor problems. Sulphide concentration remains below detectable levels until complete denitrification (Figure 2B).

Additionally, nitrate results in consumption of soluble COD and increase of $\mathrm{pH}$ via heterotrophic denitrification (Figure 2A). After complete denitrification, $\mathrm{pH}$ decreases and soluble organic substrate is produced due to the prevalence of anaerobic conditions. Temperature $(T)$, initial soluble COD to $\mathrm{NO}_{3}{ }^{-} \mathrm{N}$ ratio $(\mathrm{C} / \mathrm{N})_{0}$, volatile suspended solids (VSS) and denitrification rate $\left(\mathrm{r}_{\mathrm{DN}}\right)$ are shown in Table 1. The higher $(\mathrm{C} / \mathrm{N})_{0}$ ratio in $25^{\circ} \mathrm{C}$ compared to $30^{\circ} \mathrm{C}$ is probably responsible for the higher denitrification rate in $25^{\circ} \mathrm{C}$.

The second set shows that addition of nitrate in a septic wastewater not only inhibits sulphide production but also oxidizes sulphide via autotrophic denitrification. Interestingly, nitrate is reduced preferentially via autotrophic denitrification, oxidizing dissolved sulphide (solids lines in Figure $3 \mathrm{~B}$ ) and after its complete oxidation via heterotrophic denitrification (discontinuous lines in Figure 3B). Autotrophic denitrification seems to be promoted compare to heterotrophic denitrification (Table 2). Further experiments not presented have confirmed our observations. The calculated autotrophic $\left(r_{A D-N}\right)$ and heterotrophic $\left(r_{H D}\right)$ denitrification rate as well as sulphide oxidation rate $\left(\mathrm{r}_{\mathrm{AD}-\mathrm{HS}}\right)$ is presented in Table 3 . In respect to $\mathrm{COD}$ and $\mathrm{pH}$, the same conclusion as the ones in the first set can be inferred. 

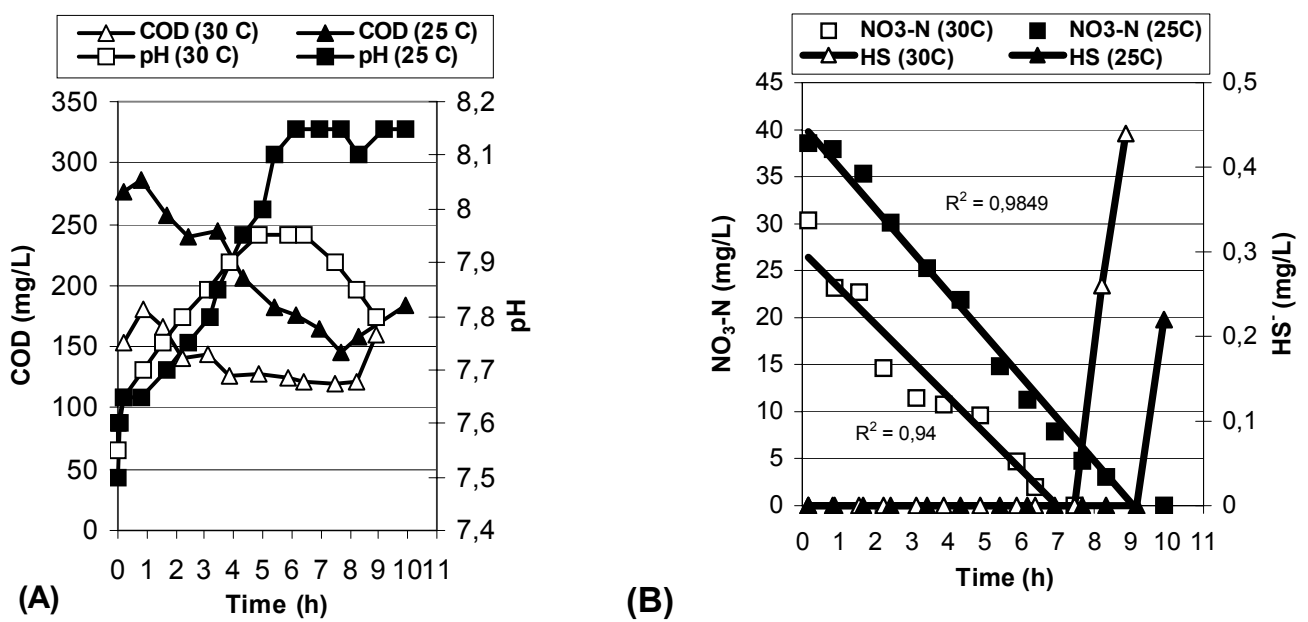

Figure 2. Soluble $\mathrm{COD}, \mathrm{pH}$, nitrate-nitrogen and total sulphide concentration versus time of the first set of experiments

(A)

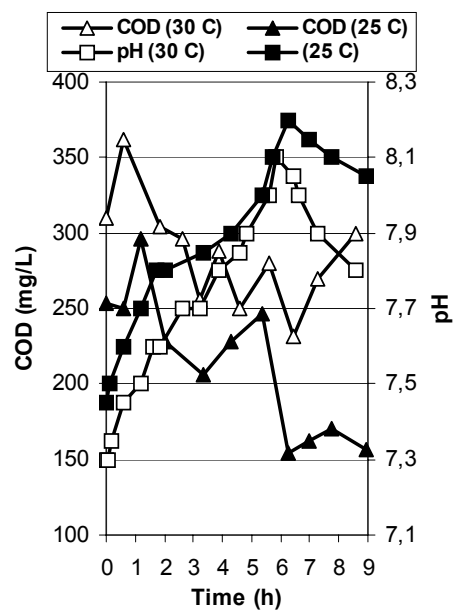

(B)

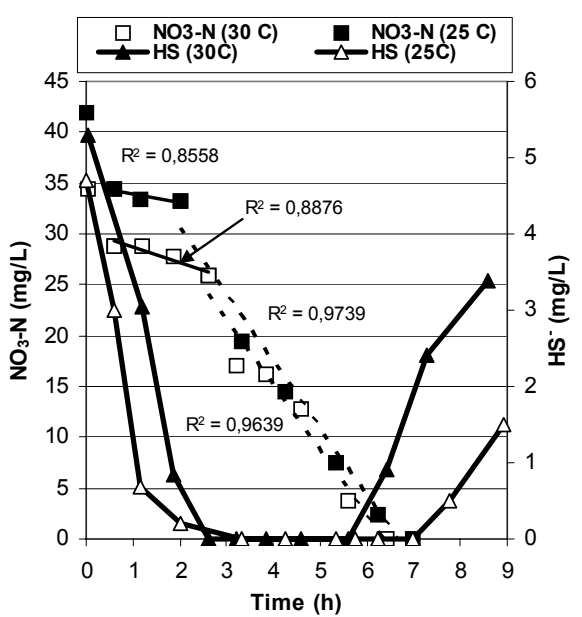

Figure 3. Soluble $\mathrm{COD}, \mathrm{pH}$, nitrate-nitrogen and total sulphide concentration versus time of the second set of experiments. (Potassium nitrate is added at $\mathrm{t}=0$ )

Table 1. Experimental data from the first set of experiments

\begin{tabular}{cccc}
\hline $\mathbf{T}\left({ }^{0} \mathbf{C}\right)$ & $(\mathbf{C} / \mathbf{N})_{0}$ & VSS $\left(\mathrm{mg} \mathrm{l}^{-1}\right)$ & $\mathbf{r}_{\mathrm{DN}}\left(\mathrm{mg} \mathrm{NO}_{3}-\mathrm{N} \mathrm{I}^{-1} \mathrm{~h}^{-1}\right)$ \\
\hline 30 & 5.07 & 926 & 3.9 \\
\hline 25 & 7.15 & 350 & 4.5 \\
\hline
\end{tabular}

Table 2. Consumption of COD during simultaneous autotrophic and heterotrophic denitrification (DN) and after complete oxidation of sulphide

\begin{tabular}{cccc}
\hline $\begin{array}{c}\mathbf{T} \\
\left({ }^{\circ} \mathbf{C}\right)\end{array}$ & $\begin{array}{c}\text { COD consumed } \\
\text { during experiments }\end{array}$ & $\begin{array}{c}\text { COD consumed until } \\
\text { sulphide oxidation (\%) }\end{array}$ & $\begin{array}{c}\text { COD consumed after } \\
\text { sulphide oxidation (\%) }\end{array}$ \\
\hline 30 & 128 & $64(50 \%)$ & $64(50 \%)$ \\
\hline 25 & 92 & $26(13.5 \%)$ & $66(86.5 \%)$ \\
\hline
\end{tabular}

Table 3. Autotrophic and heterotrophic denitrification rates in the second group of experiments

\begin{tabular}{ccccc}
\hline $\mathbf{T}\left({ }^{0} \mathrm{C}\right)$ & $\mathbf{V S S}\left(\mathrm{mg} \mathrm{l}^{-1}\right)$ & $\mathbf{r}_{\mathrm{AD}-\mathrm{HS}}\left(\mathrm{mg} \mathrm{S}^{\left.2-\mathrm{I}^{-1} \mathbf{h}^{-1}\right)}\right.$ & $\mathrm{r}_{\mathrm{AD}-\mathrm{N}}\left(\mathrm{mg} \mathrm{NO}_{3}-\mathbf{N ~ I}^{-1} \mathbf{h}^{-1}\right)$ & $\mathrm{r}_{\mathrm{HD}}\left(\mathrm{mg} \mathrm{NO}_{3}-\mathrm{N} \mathrm{I}^{-1} \mathbf{h}^{-1}\right)$ \\
\hline 30 & 875 & 2.4 & 1.5 & 6.4 \\
\hline 25 & 760 & 2.3 & 0.8 & 6.5 \\
\hline
\end{tabular}




\subsection{Field experiments}

The average temperature of the wastewater was $26.6^{\circ} \mathrm{C}$. Typical concentration of sulphide without addition of nitrate and sulphide concentration after addition of 3 different ammonia nitrate loads are presented in Figure 4. Severe problems concerning odor exist in the system despite the spontaneous oxidation of sulphide through reaeration along the gravity sewers. Continuous addition of nitrate led to oxidation of sulphide resulting in sulphide concentration below $1 \mathrm{mg} \mathrm{S}^{2-} \mathrm{I}^{-1}$, in most cases. Addition of $6.9,15$ and $27.7 \mathrm{Kg} \mathrm{NH}_{4} \mathrm{NO}_{3} \mathrm{~h}^{-1}$ led to an average decrease of sulphide in all sampling points of $83.5 \%, 97.9 \%$ and $98.8 \%$, respectively. In Figure 5A, the concentration of nitrate-nitrogen, after supplementation of nitrate, is presented. At the inlet of the WWTP, nitrate-nitrogen is not exceeding $4 \mathrm{mg} \mathrm{l}^{-1}$. Considering that the average concentration of nitrate-nitrogen in the influent, without addition of nitrate is $2.3 \mathrm{mg} \mathrm{I}^{-1}$ it can be clear that addition of nitrate does not increase the nitrate load in a prohibitory degree. In respect to ammonia, the increase of the daily Total Kjeldahl Nitrogen load, even for a high daily dosing of $665 \mathrm{Kg} \mathrm{NH}_{4} \mathrm{NO}_{3}\left(27.7 \mathrm{Kg} \mathrm{NH}_{4} \mathrm{NO}_{3} \mathrm{~h}^{-1}\right)$, is less than $10 \%$. The addition of nitrate doesn't affect the biodegradation of COD in the sewer system (Figure $5 B$ ). This observation as well as the spontaneous oxidation of sulphide observed without addition of nitrate suggests that the studied sewer system is mainly aerobic and that its anaerobic parts are responsible for the odor problems appearing.

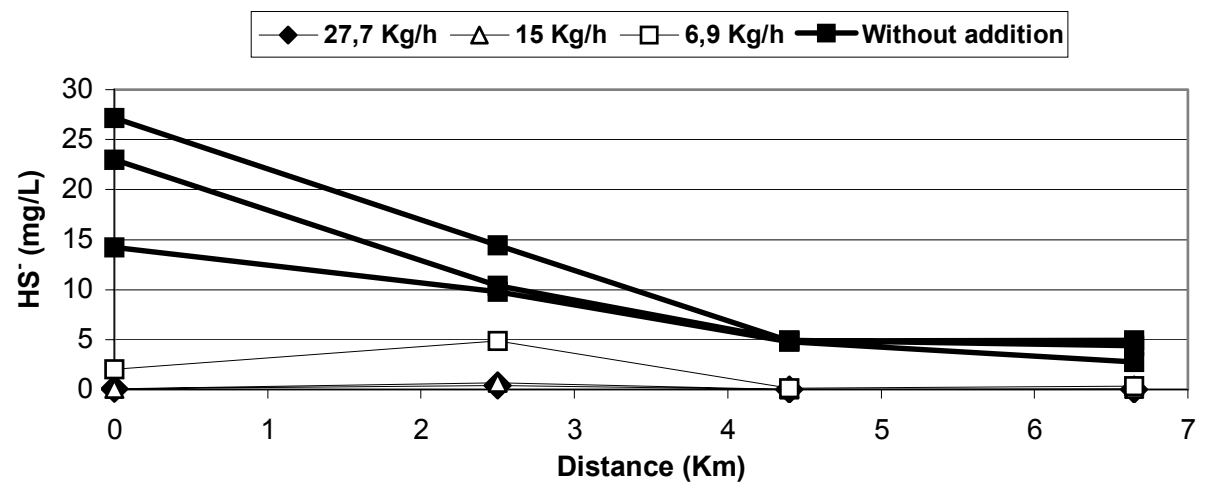

Figure 4. Concentration of total sulphide along the studied sewer network with and without addition of ammonium nitrate

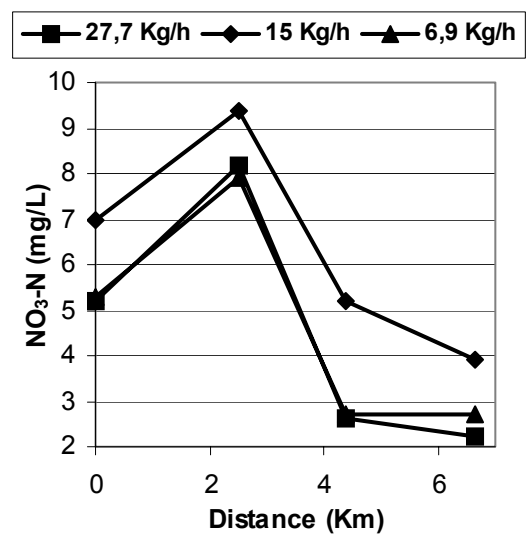

(A)

Figure 5. Nitrate-nitrogen during addition of ammoniu with and without addition of ammonium nitrate (B)

\section{CONCLUSIONS}

The effectiveness of nitrate to control odor problems has been presented not only in laboratory but also under real conditions. Based on these experimental results, a continuous addition of $240 \mathrm{Kg} \mathrm{NH}_{4} \mathrm{NO}_{3} \mathrm{~d}^{-1}$ has been proposed for practical implementation as the optimal dosing, considering sufficient odor control and tolerable increase of the ammonia load. The proposed method is not only effective but also financially feasible taking into account the 
facility cost of $2500 .-€$ and the monthly operational cost of $1250 .-€$, during the summer for the investigated sewer system.

\section{REFERENCES}

1. U.S.E.P.A. (1998) Sewer and Tank Sediment Flushing: Case Studies EPA/600/R-98/157, Chapter 4: Hydrogen sulfide and sulfuric acid estimation techniques.

2. Aesoy A., Odegaard H. and Bentzen G. (1997) The effect of sulphide and organic matter on the nitrification activity in a biofilm process, Water Science and Technology 37(1), 115-122.

3. Hvitved-Jacobsen T., Vollertsen J., Yongsiri C., Nielsen A.H., Abdul-Talib S. (2002) Sewer microbial processes, emissions and impacts, 3rd International Conference on sewer processes and networks, April 15-17, Paris, France.

4. Davidova I., Hicks M.S., Fedorak P.M. and Sufita J.M. (2001) The influence of nitrate on microbial processes in oil industry production waters, Journal of Industrial Microbiology \& Biotechnology, 27, 80-86.

5. Melidis P., Vaiopoulou E. and Aivasidis A. (2004) Autotrophic denitrification for hydrogen sulfide removal from petrochemical wastewater, $10^{\text {th }}$ World Congress of Anaerobic Digestion, Montreal, Canada

6. Gostelow P. and Parsons S.A. (2000) Sewage treatment works odour measurement, Water science and technology, 41(6), 33-40.

7. Nielsen P.H., Raunkjaer K., Norsker N.H., Jensen N.A. and Hvitved-Jacobsen T. (1992) Transformation of wastewater in sewer systems - A review, Wat. Sci. Tech., 25(6), 17-31.

8. Hvitved-Jacobsen T., Vollertsen J. and Tanaka N. (2000) An integrated aerobic/anaerobic approach for prediction of sulfide formation in sewers, Wat. Sci. Tech., 41(6), 107-115.

9. Sercombe D.C.W. (1995) The control of septicity and odours in sewerage systems and at sewage treatment works operated by Anglian Water Services Limited, Wat. Sci. Tech., 31(7), 283-292.

10. Bentzen G., Smith A.T., Bennett D., Webster N.J., Reinholt F., Sletholt E. and Hobson J. (1995) Controlled dosing of nitrate for prevention of $\mathrm{H}_{2} \mathrm{~S}$ in a sewer network and the effects on the subsequent treatment processes, Wat. Sci. Tech., 31(7), 293-302.

11. Vaiopoulou E., Kapagiannidis A., Melidis P. and Aivasidis A (2005) An activated sludge treatment plant for intergraded removal of carbon, nitrogen \& phosphorus, 9th International Conference on Environmental Science and Technology, September 1-3 2005 Rhodes, Greece. 